\title{
EXPERIMENTAL STUDIES ON THE SIGNIFICANCE OF ENDO- TOXIN IN THE PATHOGENESIS OF BRUCELLOSIS
}

\author{
By WESLEY W. SPINK AND DOROTHY ANDERSON \\ (From the Department of Medicine, University of Minnesota Hospitals and Medical School, \\ Minneapolis, Minn.)
}

(Submitted for publication October 19, 1953; accepted December 23, 1953)

The participation of an endotoxin in the pathogenesis of brucellosis has received scant recognition although clinical observations have suggested that a Brucella toxin might be responsible for some of the manifestations in the acute phases of the disease. This has been especially obvious in patients whose illness has been due to Brucella melitensis. In general, brucellosis caused by $\mathrm{Br}$. melitensis is a more severe disease than that resulting from $\mathrm{Bru}$ cella abortus (1). It has also been observed in experimentally infected guinea pigs that $\mathrm{Br}$. melitensis caused a more severe type of illness than did $B r$. abortus, although the abortus strains produced a larger number of demonstrable lesions in the tissues (2). Experience with aureomycin in the treatment of seriously ill patients with brucellosis has also suggested that an endotoxin might be responsible for some of the reactions observed after an initial dose of the antibiotic (3). Within eight to twelve hours after the first oral dose of aureomycin, an abrupt rise in temperature occurred, which was associated with a shock-like reaction, hypotension and tachycardia. Smaller initial doses of aureomycin eliminated the more severe reactions. A possible explanation for these clinical phenomena was that the antibrucella activity of the aureomycin resulted in the liberation of an agent or agents from the Brucella cells that provoked the undesired reactions. Further clinical observations that have promoted the present study were related to the dramatic improvement that occurred following the administration of adrenocorticotropin (4). No therapeutic agent available thus far for human brucellosis has resulted in a more rapid improvement in the condition of the acutely ill patient than that which has accompanied the use of either cortisone or adrenocorticotrophic hormone, even though the Brucella organisms have not been simultaneously eliminated from the tissues or blood stream. In view of the questions raised by these clinical observations, experiments were carried out to determine if the endotoxins of representative strains of the three species of Brucella differed in their toxicity for animals. The investigations were then extended to see if antibiotics or cortisone offered protection against the endotoxins. And finally, the acute lethal effect of the endotoxins was compared with that of living Brucella organisms.

The concept that the endotoxin of Brucella organisms is related to the manifestations of the disease is in accord with many studies that have been carried out with the toxins of other gram-negative bacteria (5). It is now generally agreed that the endotoxins of gram-negative organisms are associated with somatic antigens located on or near the surface of smooth cultures of the cells (6). Little or none of the endotoxic substance is associated with the surface of rough colonies. These surface factors include the $\mathrm{O}$ and $\mathrm{Vi}$ antigens, and are composed of carbohydrate-lipoid-protein complexes, in which the carbohydrate is probably the major component (7).

Miles and Pirie (8) in their basic studies on a smooth culture of $\mathrm{Br}$. melitensis isolated a complete somatic antigen, which was toxic and which had as its "core" an amino polyhydroxy antigen, designated as AP. They stated that AP was analogous to the SSS isolated by Raistrick and Topley (9) from Bacterium aertrycke and (10) from Bacterium typhosum, and by Morgan (11) from Bacterium shigae. Furthermore, AP was similar to the polysaccharide complex isolated by Boivin and Mesrobeanu (12) from different species of gramnegative organisms. AP also contained the $\mathrm{M}$ and A Brucella antigens of Wilson and Miles (13). Paterson, Pirie, and Stableforth (14) have also isolated a complete antigen from a smooth culture of $B r$. abortus, similar to, but not identical with that obtained from $\mathrm{Br}$. melitensis. The available information suggested that endotoxin from smooth cultures of Brucella could be obtained by several 
different procedures (15). In the present studies, the method of Boivin was employed, in which extraction of the Brucella cells was carried out with trichloracetic acid.

\section{METHODS OF STUDY}

Strains of Brucella. A total of 19 strains was used, and to orient the reader to the later experimental data, the strains may be identified as follows:

$\begin{array}{ccc}\begin{array}{c}\text { Brucella } \\ \text { melitensis }\end{array} & \begin{array}{c}\text { Brucella } \\ \text { suis }\end{array} & \begin{array}{c}\text { Brucella } \\ \text { abortus }\end{array} \\ 472 & 374 & 524 \\ 9 & 1960 & \text { El } 9-28 \\ 363 & 1331 & \text { El 11-10 } \\ 368 & \text { Deane } & 2061 \\ \text { Y } & 2049 & 1933 \\ & & 19 \\ & & 2068 \\ & & \text { PM Wisc. }\end{array}$

The viability of all of the strains was maintained on "Albimi" Brucella agar medium. The smooth phase of all but one of the cultures was used in the experiments to be cited. The one nonsmooth strain was 5 Wisc in the $B r$. abortus group, which possessed a mucoid type of colony. ${ }^{1}$ The five strains of $B r$. melitensis and five strains of $B r$. suis were all isolated from human subjects. Strain 472 of $B r$. melitensis and 374 of $B r$. suis have been used extensively in this laboratory over a period of several years. They are stable strains and highly virulent for guinea pigs. In the Br. abortus group, strains 524, E1 9-28, El 11-10, 2061 and 1933 were all isolated originally from the blood cultures of human patients, and all required additional carbon dioxide for growth. Strain El 9-28 was isolated from a patient who had Brucella endocarditis. Strain El 11-10 is a streptomycin-resistant culture isolated from the blood of this same patient after treatment with that antibiotic (16). Strain 524 has been used for several years in this laboratory. It is a stable, smooth strain and has been of uniform virulence in guinea pigs and mice. Strain 19 of Br. abortus was obtained from the Bureau of Animal Industry of the U. S. Department of Agriculture. It is a stable, smooth strain of low virulence that does not require added carbon dioxide for growth, and has been extensively used for immunizing cattle against Bang's disease. Strain 2068 is a subculture of strain 19 that was isolated from the blood stream of a human patient, and strain PM represents the vaccine that this patient was employing when he became infected (17).

Preparation of endotoxin. With but minor changes, the method for preparing the Boivin-type of antigen is the same procedure as that outlined by Kabat and Mayer (15). A single batch of endotoxin was started by seeding 30 rectangular bottles of $500 \mathrm{ml}$. capacity with a fresh suspension of Brucella cells. About $50 \mathrm{ml}$. of 3 per cent "Albimi" Brucella agar was dispersed over one of the

1 Obtained through the courtesy of Dr. D. T. Berman, University of Wisconsin. broad surfaces of each bottle. Incubation at $37^{\circ} \mathrm{C}$. for 48 hours was carried out and then the Brucella cells were harvested and extracted in the cold with trichloracetic acid. The centrifugate was dialyzed against running tap water; the dialysate treated with alcohol; and then the endotoxin contained in the dried precipitate was suspended in saline solution at a neutral $\mathrm{pH}$.

Test animal. Preliminary toxicity studies with the endotoxin were carried out with rabbits. Because of the large quantities of endotoxin which were necessary to establish an acute lethal end point in rabbits, mice were selected for study. When different strains of mice were employed it was observed that some strains were more resistant to the lethal action of the endotoxin than others. The most desirable and constant results were obtained with the $A B C$ strain of white male mice, weighing 15 to $20 \mathrm{Gm}$., obtained from Dr. John Bittner at the University of Minnesota. This strain of mice was used throughout in the experiments to be cited. Saline suspensions of weighed endotoxin were freshly prepared, and injected intravenously into the tail veins of the mice.

\section{RESULTS}

\section{General observations concerning the effect of Bru- cella endotoxin}

Since the endotoxin was suspended in saline solution and administered intravenously, preliminary studies were carried out to note the effect on the mice of injecting intravenously 0.5 to $1 \mathrm{ml}$. of sterile saline solution alone. No ill effects were observed. The over-all results following the injection of graded doses of endotoxin showed that a lethal outcome within 24 hours was usually associated with doses of 0.5 to $1.0 \mathrm{mg}$. In some instances death occurred after a period of two to three days had elapsed. Within a few hours following the injections of these amounts the animals began to appear ill. The fur was ruffled; the respirations were increased; there was profuse secretion from the eyes and nose; and they huddled in the corners of their cages, much less active than the control animals which had received only saline solution. A slight degree of cyanosis was apparent, and some animals had diarrhea. Deaths began to occur after 8 to 12 hours had elapsed. Post-mortem studies did not demonstrate any outstanding gross abnormalities, except for some congestion of the viscera. The lumen of the intestinal tract contained bloody, mucoid material. Microscopic examination of sections of the lungs, liver, kidney, adrenal, and intestines revealed congestion and dilated vessels. 
Comparative effects of Brucella endotoxin from different species and different strains

Results with standard strains of Br. melitensis, $B r$. suis, and $B r$. abortus. The most outstanding observation relating to the comparative effects of the various Brucella endotoxins in several hundred mice was that the lethal end point was essentially the same for each of the three species. This included experiments with five strains of $\mathrm{Br}$. melitensis (472, 9, 363, 368 and $Y)$, five strains of Br. suis (374, Deane, 2049, 1960 and 1331), and four strains of Br. abortus (524, 2061, 1933 and E1 9-28).

\section{TABLE I}

The effect of $\mathrm{Br}$. melitensis endotoxin from strain 472 in white male $A B C$ mice weighing 15 to 20 grams

\begin{tabular}{cccc}
\hline & \multicolumn{2}{c}{ Results in 24 hours } \\
\cline { 2 - 4 } Dose & $\begin{array}{c}\text { No. } \\
\text { living }\end{array}$ & $\begin{array}{c}\text { No. } \\
\text { dead }\end{array}$ & $\begin{array}{c}\text { Per cent } \\
\text { dead }\end{array}$ \\
\hline mg. & 93 & 99 & 52 \\
0.5 & 44 & 109 & 71 \\
1.0 & 4 & \\
\hline
\end{tabular}

Since the toxemia in man and in animals resulting from infection with $\mathrm{Br}$. melitensis is more severe than that which is caused by $B r$. abortus and $B r$. suis, extensive studies were carried out with the endotoxin from $\mathrm{Br}$. melitensis, especially with that from strain 472 . Table I summarizes the lethal results in several different experiments when endotoxin from strain 472 was injected into mice, and indicates that 52 per cent of the mice died within 24 hours when $0.5 \mathrm{mg}$. was injected, and 71 per cent when $1 \mathrm{mg}$. was administered. The re-

TABLE II

The effect of endotoxin from strains of $B r$. abortus in white male $A B C$ mice weighing 15 to 20 grams

\begin{tabular}{clcc}
\hline \hline \multirow{2}{*}{ Strain } & Dose & \multicolumn{2}{c}{ Results in 24 hrs. } \\
\cline { 2 - 4 } 524 & $\begin{array}{c}\text { No. } \\
\text { living }\end{array}$ & $\begin{array}{c}\text { No. } \\
\text { deaths }\end{array}$ \\
\hline \multirow{2}{*}{2061} & 0.5 & 2 & 5 \\
& 1.0 & 0 & 7 \\
1933 & 0.25 & 2 & 8 \\
& 0.5 & 0 & 5 \\
E1 9-28 & 0.25 & 4 & 1 \\
& 0.5 & 2 & 8 \\
& 0.25 & 5 & 0 \\
& 0.5 & 0 & 10 \\
\hline
\end{tabular}

sults with endotoxin from $B r$. suis were essentially the same as those obtained with $B r$. melitensis. However, when the results of one experiment with endotoxin from the four strains of $\mathrm{Br}$. abortus were compared with those of endotoxin from $\mathrm{Br}$. suis and from $\mathrm{Br}$. melitensis, the abortus endotoxin caused a higher rate of death. The results with the $B r$. abortus endotoxins are shown in Table II. However, it could not be concluded from this one experiment alone that the endotoxin from $\mathrm{Br}$. abortus had a more lethal effect than that from the other two species.

\section{Effects of endotoxins prepared from variants of Brucella abortus}

Endotoxin was prepared from strain 19, which is a stable smooth strain of $\mathrm{Br}$. abortus, and the living cells rarely establish an infection in animals. Of considerable significance is the observation that the endotoxin from this strain proved to be just as lethal in mice as were the endotoxins prepared from the more invasive culture of $\mathrm{Br}$. abortus, and was as toxic as those extracted from strains of $B r$. melitensis and $\mathrm{Br}$. suis. Another observation related to the toxicity of endotoxin made from a subculture of strain 19, known as strain 2068. This latter strain caused a serious illness in a human being (17). The endotoxin from strain 2068 was highly lethal for mice as was the endotoxin prepared from the vaccine, which was the source of strain 2068 (PM vaccine of strain 19). Results with the endotoxins from strains 19, 2068 and PM are compared in Table III with those of strain 524, which is a virulent culture of $\mathrm{Br}$. abortus.

TABLE III

Comparative lethal effect of endotoxins from a virulent culture of Br. abortus (strain 524), and from subcultures of Br. abortus, strain 19

\begin{tabular}{|c|c|c|c|}
\hline \multirow[b]{2}{*}{ Strain } & \multirow[b]{2}{*}{$\begin{array}{c}\text { Dose of } \\
\text { endotoxin }\end{array}$} & \multicolumn{2}{|c|}{ Result in 24 hrs. } \\
\hline & & $\begin{array}{l}\text { No. } \\
\text { living }\end{array}$ & $\begin{array}{l}\text { No. } \\
\text { deaths }\end{array}$ \\
\hline $\begin{array}{r}524 \\
524 \\
524 \\
19 \\
19 \\
2068 \\
2068 \\
\text { PM } \\
\text { PM }\end{array}$ & $\begin{array}{l}\text { mg. } \\
0.25 \\
0.5 \\
1.0 \\
0.5 \\
1.0 \\
0.25 \\
0.5 \\
0.25 \\
0.5\end{array}$ & $\begin{array}{l}3 \\
2 \\
0 \\
4 \\
2 \\
1 \\
0 \\
1 \\
0\end{array}$ & $\begin{array}{r}7 \\
9 \\
12 \\
1 \\
8 \\
9 \\
5 \\
9 \\
5\end{array}$ \\
\hline
\end{tabular}


Several unsuccessful attempts were made to prepare an endotoxin lethal for mice from strain 5 Wisc., which is a nonsmooth, mucoid strain of $\mathrm{Br}$. abortus. These results confirmed the observations of others that the endotoxin of Brucella, as in other gram-negative organisms, was associated only with the smooth phase.

\section{Attempts to protect mice against the lethal effect of Brucella endotoxin with antibiotics}

Penicillin. Miller, Hawk, and Boor (18) had reported that penicillin protected mice against the endotoxins of gram-negative bacteria, and similar observations were carried out in which mice were given crystalline penicillin $G$ prior to and with the administration of Brucella endotoxin. However, penicillin offered no demonstrable protection, as noted in the results of the experiment in Table IV.

Aureomycin. Since aureomycin possesses antibacterial activity against a greater range of bacterial species than does penicillin, mice were treated with crystalline aureomycin prior to receiving Brucella endotoxin. Previous experiments had demonstrated that mice could be protected against viable Brucella by mixing the antibiotic with food (19). Therefore, a group of mice were fed with aureomycin for one week in a dose of $2.2 \mathrm{Gm}$. of
TABLE IV

Failure of crystalline penicillin $G$ to protect $A B C$ mice against lethal effect of Brucella endotoxin prepared from strain 472 of $\mathrm{Br}$. melitensis

\begin{tabular}{|c|c|c|c|}
\hline \multirow[b]{2}{*}{ Treatment } & \multirow[b]{2}{*}{$\begin{array}{c}\text { Dose of } \\
\text { toxin }\end{array}$} & \multicolumn{2}{|c|}{ Results in $24 \mathrm{hrs}}$. \\
\hline & & $\begin{array}{c}\text { No. } \\
\text { living }\end{array}$ & $\begin{array}{l}\text { No. } \\
\text { deaths }\end{array}$ \\
\hline \multirow{3}{*}{$\begin{array}{l}5,000 \text { units of penicillin } 20, \\
18 \text {, and } 2 \text { hours before } \\
\text { injection of toxin } \\
\text { Saline solution } 20,18 \text {, and } \\
2 \text { hours before injection } \\
\text { of toxin }\end{array}$} & mg. & & \\
\hline & 1.0 & 0 & 10 \\
\hline & 1.0 & 3 & 8 \\
\hline
\end{tabular}

aureomycin per $\mathrm{Kg}$. of food. Then endotoxin from strain 472 was administered. Of 37 control animals that did not receive aureomycin, 12 or 34.3 per cent died within 24 hours; and 15 or 40.5 per cent of 37 mice that had been treated with aureomycin died within the same period. It was concluded that aureomycin did not protect mice against the lethal action of Brucella endotoxin.

Protection of mice by cortisone against lethal effect of Brucella endotoxin

Eight experiments involving over 300 mice were carried out in order to determine whether cortisone protected mice against the lethal action of Brucella

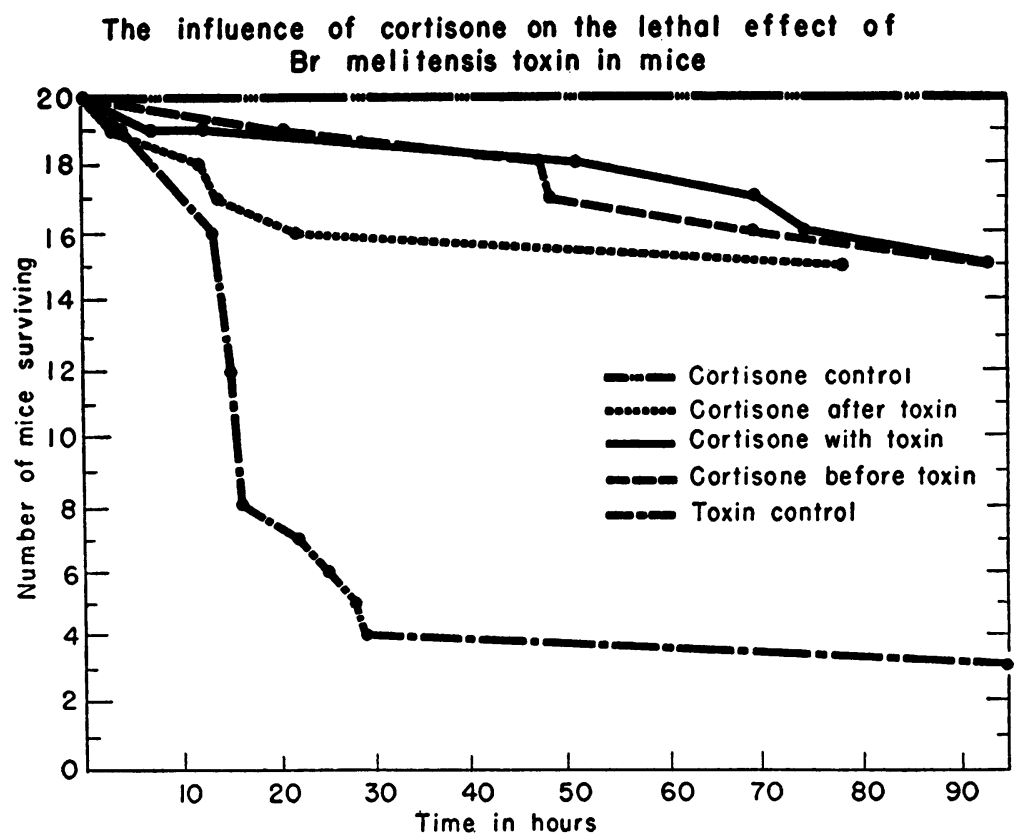

Fig. 1. The Influence of Cortisone on the Lethal Effect of $B r$. melitensis ToxIN IN MICE 
endotoxin. Preliminary experiments demonstrated that the daily injection of cortisone acetate for four days prior to the administration of the endotoxin afforded definite protection for the animals compared to control animals which were pretreated only with saline solution. It was further shown that a single injection of $0.5 \mathrm{mg}$. cortisone acetate given one hour before, simultaneously, or one hour after the injection of endotoxin offered essentially the same high degree of protection. The results of an experiment involving 100 mice, divided into five groups of 20 mice each, are presented in Figure 1. When $0.5 \mathrm{mg}$. of cortisone acetate was administered to normal mice, none of the mice succumbed. When $0.5 \mathrm{mg}$. of cortisone was administered one hour before, simultaneously, or one hour after the injection of $1.0 \mathrm{mg}$. of endotoxin prepared from strain 472, the maximum number of mice which had died within 30 hours in any of the three treated groups was 4, whereas 16 of the 20 untreated animals had died within this time.

There was a definite time limit within which cortisone was protective. Animals were protected when the cortisone was administered one hour after the mice had received endotoxin, but no protection was demonstrated when the administration of cortisone was delayed for six hours after the injection of endotoxin.

\section{Influence of thorotrast on the effect of Brucella endotoxin in mice}

The mechanism whereby endotoxin is successfully disposed of in the body is not clearly understood, but Beeson (20) has suggested that the reticuloendothelial system may be involved. $\mathrm{He}$ observed that the administration of thorotrast (thorium dioxide) to animals reduced their tolerance to bacterial pyrogens from gram-negative organisms. In view of this, mice were prepared with thorotrast ${ }^{2}$ and then injected with Brucella endotoxin. A 25 per cent solution of thorotrast was prepared and 0.2 to $0.3 \mathrm{ml}$. was given intravenously. Repeated observations demonstrated that the thorotrast was not a benign agent. There was a critical level beyond which the material was not tolerated. In contrast with the protection afforded by cortisone, thorotrast enhanced the lethal action of Brucella endotoxin by virtue of the toxic action of thorotrast itself, or because it prevented the reticulo-endothelial cells from taking up the endotoxin. In a typical experiment illustrated in

${ }^{2}$ Lot No. 129 thorium dioxide, Heyden Chemical Corp.

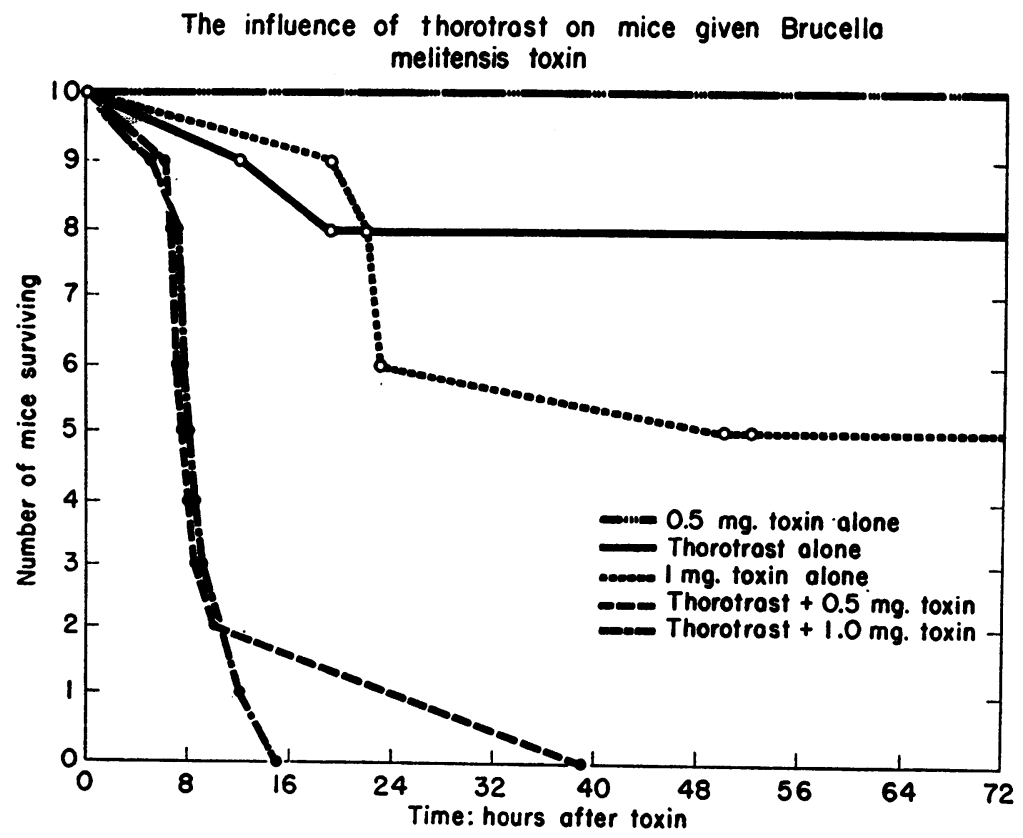

Fig. 2. The Influence of Thorotrast on Mice Given Brucella melitensis Toxis 
Figure 2 five groups of 10 mice each were employed. One group of animals was given $0.5 \mathrm{mg}$. of Brucella endotoxin prepared from strain 472 and another group was given $1.0 \mathrm{mg}$. Two similarly treated groups had been given $0.2 \mathrm{ml}$. of the thorotrast solution three and one-half hours before the endotoxin, and it is noted that the thorotrast-treated group succumbed earlier and in larger numbers to the endotoxin than those receiving endotoxin alone.

Several experiments were carried out to determine if mice treated with endotoxin could be protected with cortisone against the deleterious action of thorotrast. No clear-cut evidence could be obtained demonstrating that cortisone did protect thorotrast-treated animals receiving endotoxin. However, the animals which survived the combination of thorotrast and endotoxin appeared to be in a better state of health when cortisone had also been given.

\section{Comparative lethal effect in mice of living cultures of Brucella}

The experimental data up to this point revealed that the endotoxin prepared from all of the strains of Brucella within each of the three species had essentially the same degree of toxicity, provided that the material was prepared from smooth cultures. It appeared that the endotoxin from a highly invasive and virulent strain of $\mathrm{Br}$. melitensis, like strain 472, was no more lethal for mice than was the endotoxin prepared from a strain of $B r$. abortus, such as strain 19, which in the living state is much less invasive. Therefore, a series of experiments were carried out in mice comparing the acute lethal effect of living organisms from representative Brucella strains in each of the three species. Forty-eight hour cultures of Brucella were suspended in saline solution and injected intravenously. Preliminary experiments with the more virulent strains indicated that 5 to 10 billion Brucella cells caused death within 24 hours.

A critical experiment is illustrated in Figure 3. Four groups of 10 mice each were injected with viable Brucella cells, each group receiving a different strain. All of the mice receiving an inoculation with a standard strain of $\mathrm{Br}$. suis, $\mathrm{Br}$. melitensis or Br. abortus died within 24 hours. However, death was delayed in the mice that received strain 19 of $\mathrm{Br}$. abortus. The results of a second experiment are presented in Figure 4. Each of four groups of six mice were injected with 50 billion organisms from a strain of Br. abortus. Strain El 9-28 and Lynch 524 are standard virulent strains

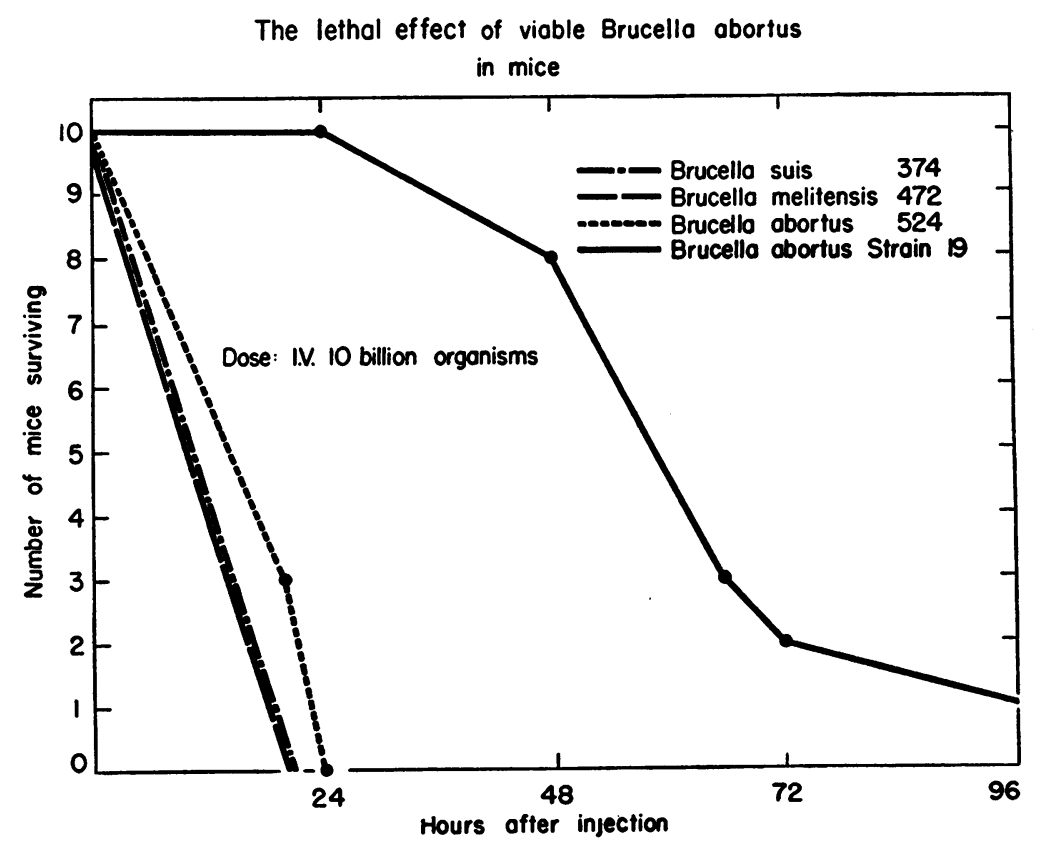

Fig. 3. The Lethal Effect of Viable Brucella abortus in Mice 


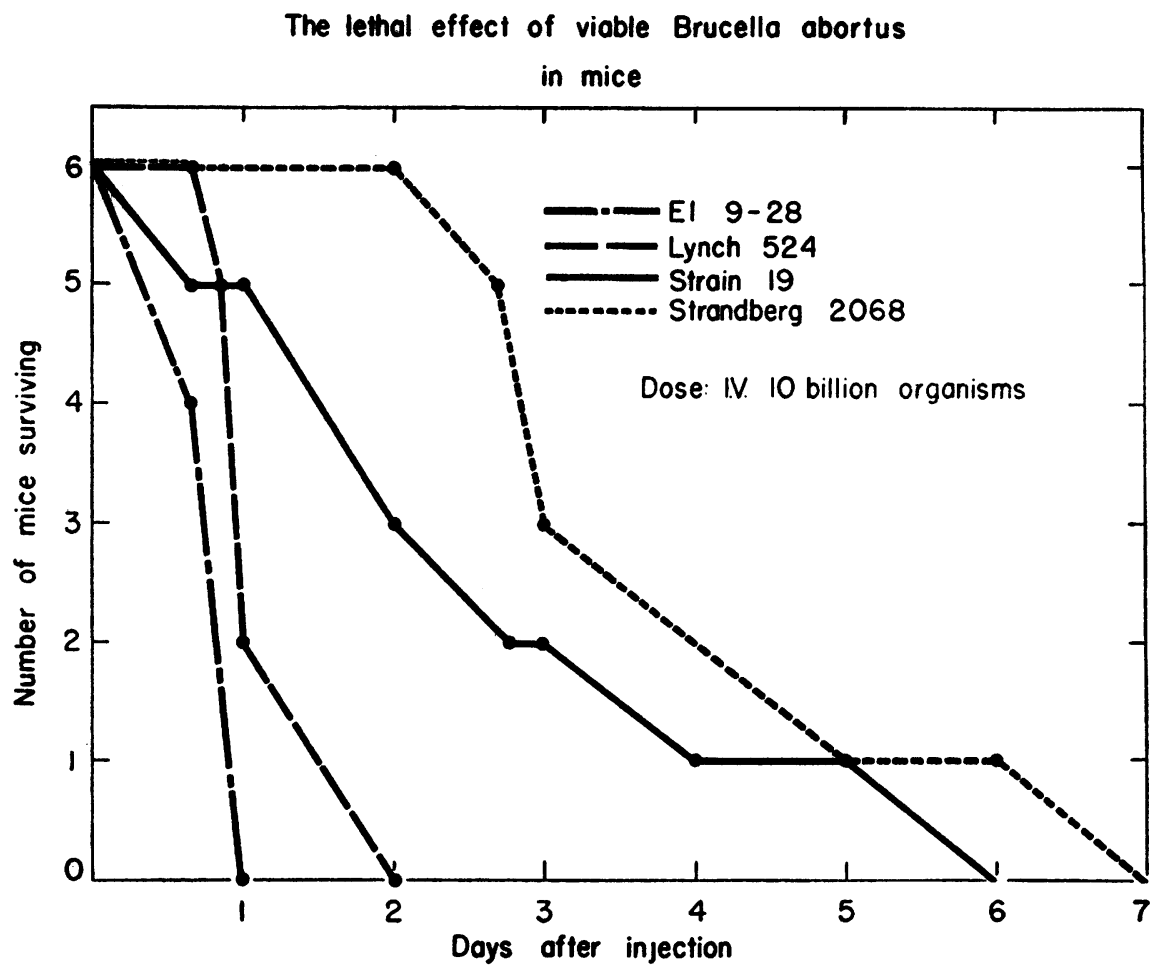

Fig. 4. The Lethal Effect of Viable Brucella abortus in Mice

of $B r$. abortus and killed all the mice within 24 to 48 hours. Strain 19 and a subculture of strain 19 known as 2068 and cultured from the blood of Strandberg caused delayed deaths. Nevertheless, endotoxins prepared from each of the four strains had the same acute lethal activity in mice.

\section{DISCUSSION}

The present studies have demonstrated that the endotoxin of smooth Brucella cultures has essentially the same lethal effect in mice, irrespective of the strain or species of Brucella from which the endotoxin has been prepared. Furthermore, the lethality of the endotoxin was not related to the invasiveness of the living micro-organisms. The endotoxin prepared from a strain, like strain 19 of $B r$. abortus, had just as devastating an effect in mice as the endotoxin obtained from a highly invasive strain of $\mathrm{Br}$. melitensis. It could be postulated that illness in man, especially in the more acute phase, was related to the action of liberated endotoxin. Toxemia is a prominent feature of brucellosis due to $\mathrm{Br}$. melitensis because this species is more invasive and the bacteria multiply more rapidly in the host. This multiplication of bacteria in turn liberates more endotoxin. If appropriate conditions were present so that the much less invasive strain of $\mathrm{Br}$. abortus, strain 19, could multiply readily in human tissues, it is not unlikely toxemia would also be apparent. This is precisely what has been observed recently in a human case of brucellosis, in which a veterinarian became infected with strain 19. Because of the significance of the observations, the details of this patient's illness have been presented elsewhere (17). He was acutely ill, and exhibited a state of profound toxemia such as is commonly seen in brucellosis due to $\mathrm{Br}$. melitensis, and in typhoid fever. That the organisms of strain 2068 were reproducing in his body was proved by the fact that they were cultured from his blood. The patient recovered promptly as a result of treatment with antibiotics. The culture from this patient is strain 2068, which has the same characteristics as strain 19. While living cells of strain 2068 were less invasive and virulent for mice than were organisms from a strain of $\mathrm{Br}$. melitensis, the endotoxin prepared from strain 2068 was just as lethal as those prepared 
from the more virulent strains of $B r$. melitensis, $B r$.abortus, and Br. suis.

The toxicity displayed by patients with acute brucellosis is quite similar to that observed in individuals with illness due to other species of gramnegative bacteria, particularly in those patients having typhoid fever. Favorite and Morgan (21) have presented evidence in investigations on human subjects indicating that the release of endotoxin by Salmonella typhosa is the cause of the toxicity in typhoid fever. Further confirmatory evidence along these lines was reported subsequently by Neva and Morgan (22). Dennis and Saigh (23) have recovered the somatic antigen of $S$. typhosa from patients with typhoid fever. Cortisone is also quite effective in subduing the toxicity in human patients with typhoid fever (24).

While the present study, and the related investigations of others, indicate that the somatic antigen of gram-negative organisms contributes to the toxic manifestations of disease, little is known pertaining to the basic mechanism or mechanisms whereby the endotoxins exert their deleterious effects. Experimental studies now in progress indicate that Brucella endotoxin in mice causes a severe depression of adrenal function.

\section{SUMMARY}

The somatic antigen, or endotoxin, from smooth cultures of Brucella organisms was prepared according to the method of Boivin and the lethal activity of the material was determined with a strain of $A B C$ white male mice. It was observed that regardless of the invasiveness and virulence of the living Brucella cells, the lethal action of the endotoxin was of the same degree for all strains of Brucella, which included the three different species, provided that smooth cultures were employed in the preparation of the material. Cortisone protected the animals against the lethal action of the endotoxin, but pretreatment or simultaneous therapy with antibiotics had no effect on the outcome. The administration of thorotrast abetted the action of the endotoxin.

The fact that the endotoxin from a strain of $B r$. abortus of low virulence was just as lethal as the endotoxin from a highly invasive strain of $\mathrm{Br}$. melitensis, suggested that the toxemia exhibited in the acute phase of human brucellosis was related to the activity of liberated somatic antigen. It was postulated that if the human host permitted the rapid multiplication of the less virulent strains of Brucella, such as strain 19 of $B r$. abortus, the toxemia might be just as severe as seen in patients infected with a highly invasive strain of $\mathrm{Br}$. melitensis. Human disease due to strain 19 rarely occurs, but a severe state of toxemia was observed in a young adult male from whose blood strain 19 was cultured. A similar relationship between toxicity and the somatic antigen probably occurs with other gram-negative species, particularly typhoid fever.

\section{REFERENCES}

1. Spink, W. W., Observations on brucellosis due to Brucella melitensis. Bull. World Health Org., 1953, 9, 385.

2. Braude, A. I., Studies in the pathology and pathogenesis of experimental brucellosis. I. A Comparison of the pathogenicity of Brucella abortus, Brucella melitensis, and Brucella suis for guinea pigs. J. Infect. Dis., 1951, 89, 76.

3. Spink, W. W., Braude, A. I., Castaneda, M. R., and Goytia, R. S., Aureomycin therapy in human brucellosis due to Brucella melitensis. J. A. M. A., 1948, 138, 1145.

4. Spink, W. W., and Hall, W. H., The influence of cortisone and adrenocorticotrophic hormone on brucellosis. II. Adrenocorticotrophic hormone (ACTH) in acute and chronic human brucellosis. J. Clin. Invest., 1952, 31, 958.

5. Van Heyningen, W. E., Bacterial Toxins. Oxford, Blackwell Scientific Publications, 1950.

6. Spooner, E. T. C., The nature of bacterial surfaces in The Nature of the Bacterial Surface. A Symposium of the Society for General Microbiology, 1949, ed. by A. A. Miles and N. W. Pirie, Oxford, Blackwell Scientific Publications, 1949, 109.

7. Morgan, W. T. J., The surface structure of Shigella shigae as revealed by antigenic analysis in The Nature of the Bacterial Surface. A Symposium of the Society for General Microbiology, 1949, ed. by A. A. Miles and N. W. Pirie, Oxford, Blackwell Scientific Publications, 1949, 23.

8. Miles, A. A., and Pirie, N. W., The properties of antigenic preparations from Brucella melitensis: I. Chemical and physical properties of bacterial fractions. Brit. J. Exper. Path., 1939, 20, 83 ; II. Serological properties of the antigens. Ibid., 1939, 20, 109; III. The biological properties of the antigen and the products of gentle hydrolysis. Ibid., 1939, 20, 278.

9. Raistrick, H., and Topley, W. W. C., Immunizing fractions isolated from Bact. aertrycke. Brit. J. Exper. Path., 1934, 15, 113.

10. Topley, W. W. C., Raistrick, H., Wilson, J., Stacey, M., Challinor, S. W., and Clark, R. O. J., The im- 
munizing potency of antigenic components isolated from different strains of Bact. typhosum. Lancet, 1937, 1, 252.

11. Morgan, W. T. J., Studies in immuno-chemistry. II. The isolation and properties of a specific antigenic substance from $B$. dysenteriae (shiga). Biochem. J., 1937, 31, 2003.

12. Boivin, A., and Mesrobeanu, L., Remarques concernant la technique d'extraction du complexe polysaccharidique antigénique renfermé dans le Bacille d'Aertrycke. Compt. rend. Soc. de biol., 1934, 115, 304.

13. Wilson, G. S., and Miles, A. A., The serological differentiation of smooth strains of the Brucella group. Brit. J. Exper. Path., 1932, 13, 1.

14. Paterson, J. S., Pirie, N. W., and Stableforth, A. W., Protective antigens isolated from $\mathrm{Br}$. abortus. Brit. J. Exper. Path., 1947, 28, 223.

15. Kabat, E. A., and Mayer, M. M., Boivin-type Antigens in Experimental Immunochemistry. Springfield, Charles C Thomas, 1948, 514.

16. Hall, W. H., and Spink, W. W., In vitro sensitivity of Brucella to streptomycin : Development of resistance during streptomycin treatment. Proc. Soc. Exper. Biol. \& Med., 1947, 64, 403.

17. Spink, W. W., and Thompson, H., Human brucellosis caused by Brucella abortus, strain 19. J. A. M. A., 1953, 153, 1162.
18. Miller, C. P., Hawk, W. D., and Boor, A. K., Protection against bacterial endotoxins by penicillin and its impurities. Science, 1948, 107, 118.

19. Shaffer, J. M., Kucera, C. J., and Spink, W. W., The protection of intracellular Brucella against therapeutic agents and the bactericidal action of serum. J. Exper. Med., 1953, 97, 77.

20. Beeson, P. B., Tolerance to bacterial pyrogens. I. Factors influencing its development. J. Exper. Med., 1947, 86, 29.

21. Favorite, G. O., and Morgan, H. R., Effects produced by the intravenous injection in man of a toxic antigenic material derived from Eberthella typhosa: clinical, hematological, chemical and serological studies. J. Clin. Invest., 1942, 21, 589.

22. Neva, F. A., and Morgan, H. R., Tolerance to the action of endotoxins of enteric bacilli in patients convalescent from typhoid and paratyphoid fevers. J. Lab. \& Clin. Med., 1950, 35, 911.

23. Dennis, E. W., and Saigh, A. S., Precipitable typhoid somatic antigen in the serum of typhoid fever patients. Science, 1945, 102, 280.

24. Woodward, T. E., Hall, H. E., Dias-Rivera, R., Hightower, J. A., Martinez, E., and Parker, R. T., Treat ment of typhoid fever. II. Control of clinical manifestations with cortisone. Ann. Int. Med., 1951, 34, 10. 